\title{
SETTING RUANG DAN PENGARUHNYA TERHADAP AKSESIBILITAS PARA PENYANDANG CACAT TUBUH DI PUSAT REHABILITASI YAKKUM YOGYAKARTA
}

\author{
Muhammad Sholahuddin*
Program Studi Desain Interior, Fakultas Seni Rupa, Institut Seni Indonesia Yogyakarta
}

The number of difable persons in Indonesia according to $W H O$ is $7 \%-10 \%$ from total population and only a small number of them have adequate education and decent job. This condition is due to the lack of accessibility facilities in public spaces and in this condition they need an institution or a community which cares and encourages positive attitude. One institution which provides such services is YAKKUM rehabilitation centre located in Yogyakarta. In general this research is intended to identity the impact of room setting to accessibility of the difable. The specific purpose of the research is to recognize impact of room setting and other factors toward difable accessibility in YAKKUM. This research uses a deductive method with Applied purposive sampling to ten room based on its tool aid properties. Data were collected with triangulation method and analyzed descriptively. SPSS was used to analyze. The quantitative data in comparing factors of room setting which has impact on accessibility. Observed variables including room setting (dimension and form, furniture and lay out, and environmental element of room). The result of this study shows that the accessibility in receptionist room was influenced by lay out and furniture, lighting, air movement; Office room: lighting, air movement; Class room: lighting and air movement; Library room: furniture and lay out, lighting, air movement; Social room: knob, lay out, and lighting; dining room: lay out, lighting and air movement; Laundry room: furniture; Physiotherapy room: knob, furniture and lay out; Hostel room: furniture; and Toilet influenced by knob, furniture and lay out, lighting, air movement. This study also found factors of room setting which influenced accessibility for difable in YAKKUM. These factors are the type of furniture, and lay out, lighting, air movement and dimension of switch control.

Key Words: Setting Room, Accessibility, Difable

Ada hubungan timbal balik antara arsitektur lingkungan (setting ruang) \& perilaku manusia. Menurut Amos Rapoport (dalam Haryadi, 1995), kajian arsitektur lingkungan \& perilaku salah satunya berkaitan tentang bagaimana lingkungan terbangun mempengaruhi perilaku manusia didalamnya \& unsur-unsur fisik yang menyebabkan manusia berperilaku berbeda dalam satu setting. Perilaku dioperasionalisasikan sebagai kegiatan manusia yang membutuhkan setting/wadah kegiatan berupa ruang. 12 atribut yang muncul dari interaksi manusia dan lingkungan yaitu kenyamanan, sosialitas, visibilitas, aksesibilitas, adaptabilitas, rangsangan inderawi, kontrol, aktivitas, kesesakan (crowdedness), privasi, makna, legibilitas
(Weisman, 1981).

Populasi penduduk Indonesia adalah 206.939.000 orang. Jumlah penyandang cacat di Indonesia menurut Badan Dunia WHO ada sekitar $7 \%-10 \%$ dari total populasi penduduk. Populasi penyandang cacat di Yogyakarta adalah 159.950 orang sedangkan yang cacat fisik ada 43.826 orang. Dari jumlah tersebut di atas ternyata hanya sebagian kecil saja yang mendapat pendidikan $(5 \%)$ dan pekerjaan $(20 \%$ ) yang layak (Suara Merdeka edisi 18 Nov 2003). Minimnya jumlah tersebut disebabkan oleh beberapa faktor

*Korespondensi penulis dialamatkan ke Program Studi Desain Interior, Fakultas Seni Rupa, Institut Seni Indonesia Yogyakarta, Tel/Fax: +62 274417219 e-mail: adind@isi.ac.id 
penghambat yang salah satunya adalah tidak memadainya aksesibilitas yang aksesibel bagi penyandang cacat khususnya pada fasilitas-fasilitas umum. Dengan kondisi seperti itu yang mereka butuhkan adalah suatu wadah atau komunitas yang dapat lebih memperhatikan dan menumbuhkan sikap mental yang positif dalam diri mereka yaitu pusat rehabilitasi. Salah satu pusat rehabilitasi penyandang cacat tubuh yang ada di Yogyakarta adalah Pusat Rehabilitasi YAKKUM Yogyakarta yang dibangun sesuai dengan standart untuk kaum difabel, namun dalam proses pemakaiannya ternyata banyak setting ruang yang berubah sehingga mempengaruhi aksesbilitas para penyandang cacat.

Ada hubungan antara arsitektur lingkungan dan perilaku penyandang cacat tubuh yang berbeda-beda pada setting ruang di pusat rehabilitasi YAKKUM Yogyakarta yang membutuhkan kemudahan aksesibilitas dalam melakukan aktivitas mereka agar aman \& nyaman.

Penelitian ini diadakan untuk menyelidiki seperti apakah pengaruh setting ruang terhadap aksesibilitas (accessibility) para penyandang cacat tubuh di Pusat Rehabilitasi Penyandang Cacat Tubuh YAKKUM Yogyakarta; dan Faktor-faktor apasaja dari setting ruang yang mempengaruhi aksesibilitas (accessibility) para penyandang cacat tubuh di Pusat Rehabilitasi Penyandang Cacat Tubuh YAKKUM Yogyakarta

Penelitian ini bertujuan untuk mengidentifikasi pengaruh setting ruang terhadap aksesbilitas para penyandang cacat tubuh dan faktor-faktor apasajakah yang mempengaruhi aksesibilitas (accessibility) para penyandang cacat tubuh di Pusat Rehabilitasi Penyandang Cacat Tubuh YAKKUM Yogyakarta.

Menurut Bride, seorang ahli dari pusat rehabilitasi cacat tubuh $\mathrm{AS}$, cacat cubuh adalah suatu perubahan bentuk tubuh yang mengakibatkan turunnya kemampuan yang normal untuk melakukan gerakan-gerakan tubuh tertentu. Sedangkan Dissability (orang cacat) adalah kondisi fisik atau mental seseorang yang terbatas berfungsi dan beraktifitas.

Dari dua pengertian diatas, dapat diambil pengertian bahwa cacat tubuh adalah perubahan kondisi fisik atau mental seseorang sehingga mengakibatkan terbatasanya kemampuan yang normal dalam berfungsi dan beraktifitas.

Pengertian khusus rehabilitasi adalah proses refungsionalisasi dan pengembangan untuk memungkinkan penderita cacat mampu melaksanakan fungsi sosialnya secara wajar dalam kehidupan masyarakat.

Rehabilitasi adalah perbaikan para penderita cacat agar bisa berbuat atau memiliki semaksimal mungkin kegunaan jasmaniah, rohaniah, sosial, pekerjaan, dan ekonomi.

Pusat rehabilitasi menurut The National Council on Rehabilitation (1943) sebagai tempat pemulihan bagi para penyandang cacat tubuh agar pulih secara fisik, mental, sosial, serta mendapat penghasilan dari keterampilan yang dimiliki.

Dalam studi tentang hubungan arsitektur lingkungan \& perilaku dalam kaitannya dengan tata ruang, perilaku dioperasionalisasikan sebagai kegiatan manusia yang membutuhkan setting (tata ruang yang terkait dengan kegiatan) atau wadah kegiatan yang berupa ruang (Haryadi, 1995). Sedangkan ruang diartikan sebagai suatu petak yang dibatasi oleh dinding dan atap baik oleh unsur yang permanen ataupun tidak permanen. Dalam kaitannya dengan manusia, hal paling penting dari pengaruh ruang terhadap perilaku manusia adalah fungsi atau pemakaian dari ruang tersebut (Haryadi , 1995).

Perancangan fisik dari setting ruang yang mempengaruhi perilaku pemakai adalah ukuran \& bentuk ruang, perabot \& penataanya, warna ruang, suara, temperatur \& pencahayaan (Haryadi, 1995).

\section{Aksesibilitas (Accessibility)}

Aksesibilitas adalah kemudahan bergerak melalui dan menggunakan lingkungan. Kemudahan bergerak yang dimaksud adalah berkaitan dengan sirkulasi (jalan) dan visual ( Weisman, 1981)

Hal-hal yang berkaitan dengan aksesibilitas adalah bangunan, elemen bangunan, kamar kecil (toilet), pintu, ramp, ruang, ruang lantai bebas, rute aksesibel, tangga (Holmes, James, 1998). 
Asas aksesibilitas:

a. Kemudahan, yaitu setiap orang dapat mencapai semua tempat atau bangunan yang bersifat umum dalam suatu lingkungan.

b. Kegunaan, yaitu setiap orang harus dapat mempergunakan semua tempat atau bangunan yang bersifat umum dalam suatu lingkungan. c. Keselamatan, yaitu setiap bangunan dalam suatu lingkungan terbangun harus memperhatikan keselamatan bagi semua orang.

d. Kemandirian, yaitu setiap orang harus bisa mencapai, masuk dan mempergunakan semua tempat dalam suatu lingkungan dengan tanpa membutuhkan bantuan orang lain.

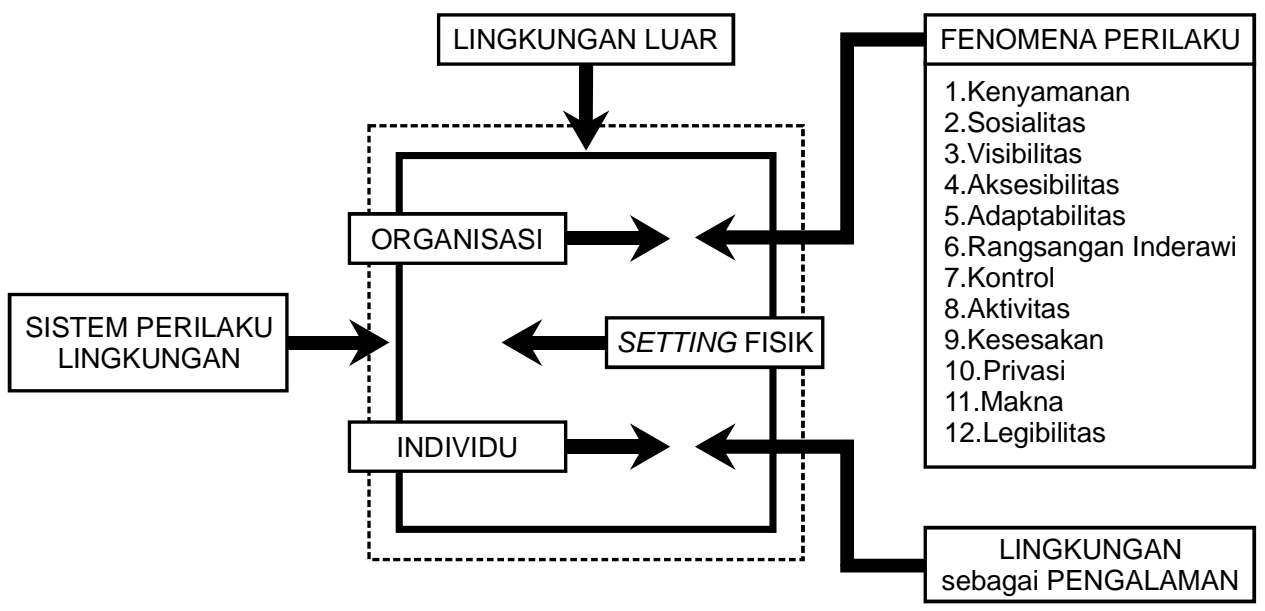

Gb.1. Diagram Grand Teori

(Sumber: Weismen, 1981)

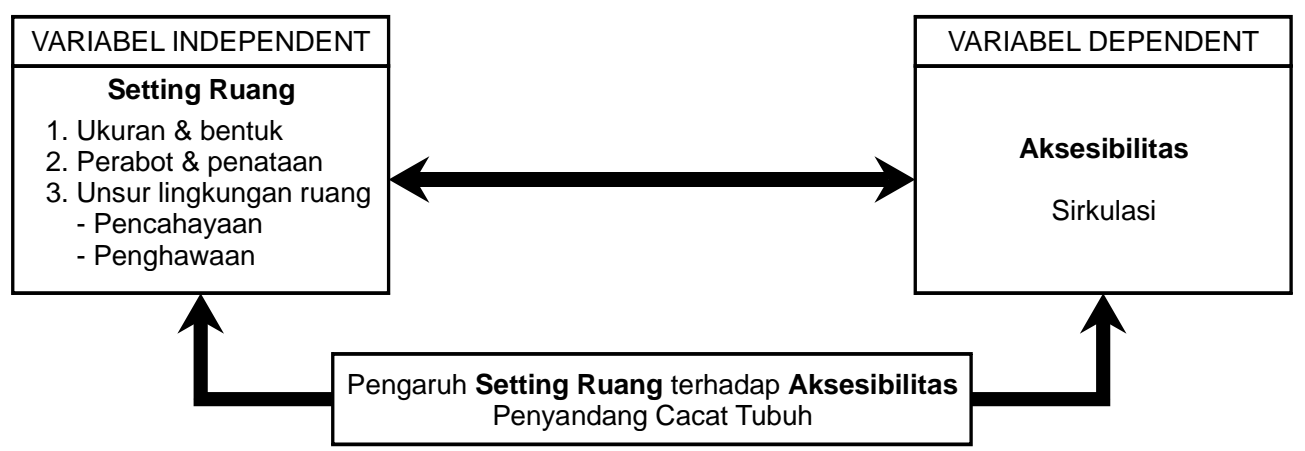

Gb.2. Kerangka Konsep Penelitian 
Tabel 1. Parameter dari Setting Ruang

\begin{tabular}{|c|c|c|}
\hline No. & Variabel Setting Ruang & Parameter \\
\hline 1 & Ukuran \& Bentuk & $\begin{array}{l}\text { - Ukuran pintu \& jendela, perletakan tombol-tombol } \\
\text { kontrol (saklar lampu, stop kontak) yang sesuai } \\
\text { dengan standar desain yang aksesibel } \\
\text { (Departemen Pekerjaan Umum, 1998). }\end{array}$ \\
\hline 2 & Perabot \& Penataan & $\begin{array}{l}\text { - Ukuran dan bentuk perabot sesuai standar tubuh } \\
\text { penyandang cacat fisik (Departemen Pekerjaan } \\
\text { Umum,1998; DeChiara, J.Panero, J\&Zelnik.M,2001; } \\
\text { Sorenson, 1979; Suma'mur, 1989) } \\
\text { - Penataan perabot yang memudahkan ruang gerak } \\
\text { (Departemen Pekerjaan Umum, 1998) }\end{array}$ \\
\hline 3 & Pencahayaan & $\begin{array}{l}\text { - Pencahayaan alami: } \\
\text { Lubang cahaya optimal adalah } 20 \% \text { dari luas lantai } \\
\text { (Reinhold, 1959), kuat cahaya sesuai fungsi } \\
\text { ruang (Darmasetiawan, 1999; Neufert, 1985; } \\
\text { Sastrowinito,1985). } \\
\text { - Pencahayaan buatan: } \\
\text { Jumlah lampu (Darmasetiawan, 1999) }\end{array}$ \\
\hline 4 & Penghawaan & $\begin{array}{l}\text { - Tingkat suhu rata-rata yang sesuai standar berkisar } \\
\text { antara } 24-27,6^{\circ} \mathrm{C} \text { (Wignjosoebroto, 1995; } \\
\text { Sastrowinoto, 1985; Suma'mur, 1989). }\end{array}$ \\
\hline
\end{tabular}

\section{BAHAN DAN METODE}

Penelitian ini menggunakan pendekatan rasionalistik dan metode deduktif dengan sampel terhadap 10 (sepuluh) ruang dengan penentuan partisipan secara purposive sampling berdasarkan dengan jenis alat bantu yang digunakan oleh penyandang cacat tubuh. Pengumpulan data dengan metode trianggulasi (observasi, quesioner dan content analisis). Variabel yang diteliti: 1) setting ruang (ukuran dan bentuk, perabot dan penataannya, dan unsur lingkungan ruang), 2) aksesibilitas (sirkulasi). Analisis dengan cara verifikasi, dianalisis secara deskriptif kualitatif dibantu dengan analisis kuantitatif (SPSS), dan dikomparatifkan untuk menemukan sejumlah faktor dari setting ruang yang berpengaruh terhadap aksesibilitas. 


\section{HASIL DAN PEMBAHASAN}

Berdasarkan analisis SPSS didapat pengaruh setting ruang terhadap aksesibilitas para penyandang cacat tubuh terlihat pada jenis ruang yang ada di YAKKUM Yogyakarta yaitu:

Aksesibilitas penyandang cacat tubuh di ruang resepsionis sudah aksesibel jika dilihat dari perabot dan penataannya, pencahayaan, dan penghawaan. Pengaruh pencahayaan dan penghawaan dari ruang resepsionis sangat signifikan terhadap aksesbilitas penyandang cacat tubuh. Pemakai kursi roda tidak aksesibel dalam hal ukuran dan bentuk dari ruang resepsionis.

Aksesibilitas penyandang cacat tubuh di ruang kantor sudah aksesibel jika dilihat dari pencahayaan dan penghawaan; cukup aksesibel dilihat dari ukuran dan bentuk serta perabot dan penataannya kecuali pemakai kursi roda merasa tidak aksesibel karena perabot dan penataannya.

Aksesibilitas penyandang cacat tubuh di ruang kelas sudah aksesibel jika dilihat pencahayaan dan penghawaan; cukup aksesibel dilihat dari ukuran dan bentuk; tidak aksesibel dilihat dari perabot dan penataaan terutama pemakai kursi roda. Pengaruh penghawaan dari ruang kelas sangat signifikan terhadap aksesbilitas penyandang cacat tubuh.

Aksesibilitas penyandang cacat tubuh di ruang perpustakaan paling tidak aksesibel jika dilihat dari ukuran dan bentuk, perabot dan penataannya, pencahayaan, dan penghawaan. Ruang perpustakaan paling tidak aksesibel untuk semua penyandang cacat tubuh.

Aksesibilitas penyandang cacat tubuh di ruang sosial sudah aksesibel jika dilihat dari ukuran dan bentuk, perabot dan penataannya, pencahayaan, dan penghawaan. Pengaruh perabot dan penataannya dari ruang sosial sangat signifikan terhadap aksesbilitas penyandang cacat tubuh.

Aksesibilitas penyandang cacat tubuh di ruang makan aksesibel jika dilihat dari ukuran dan bentuk, perabot dan penataannya, pencahayaan, dan penghawaan. Pengaruh ukuran dan bentuk dari ruang makan sangat signifikan terhadap aksesibilitas penyandang cacat tubuh.

Aksesibilitas penyandang cacat tubuh di ruang cuci tidak aksesibel jika dilihat dari

Tabel 2. Pengaruh Setting Ruang Terhadap Aksesibilitas Berdasarkan Analisis SPSS

\begin{tabular}{|c|c|c|c|c|c|c|c|c|c|c|c|c|c|c|c|c|}
\hline \multirow[t]{2}{*}{ Jenis Ruang } & \multicolumn{4}{|c|}{$\begin{array}{c}\text { Ukuran \& } \\
\text { Bentuk }\end{array}$} & \multicolumn{4}{|c|}{$\begin{array}{l}\text { Perabot \& } \\
\text { Penataan }\end{array}$} & \multicolumn{4}{|c|}{ Pencahayaan } & \multicolumn{4}{|c|}{ Penghawaan } \\
\hline & KR & $\mathbf{K}$ & DLL & HP & KR & $\mathbf{K}$ & DLL & HP & KR & $\bar{K}$ & DLL & HP & KR & $\mathrm{K}$ & DLL & HP \\
\hline R. Resep & $\mathrm{TA}$ & $A$ & $\mathrm{TA}$ & TA & $A$ & $\mathrm{~A}$ & $A$ & $\mathrm{~A}$ & $A$ & $A$ & $A$ & $A$ & $\mathrm{~A}$ & $\mathrm{~A}$ & $A$ & $A$ \\
\hline R. Kantor & $\mathrm{CA}$ & $\mathrm{CA}$ & $\mathrm{CA}$ & $\mathrm{CA}$ & TA & A & $\mathrm{CA}$ & $\mathrm{CA}$ & $A$ & $A$ & TA & $A$ & $A$ & $\mathrm{CA}$ & $\mathrm{CA}$ & $A$ \\
\hline R. Kelas & $A$ & $\mathrm{CA}$ & TA & $\mathrm{CA}$ & TA & $\mathrm{CA}$ & $\mathrm{CA}$ & $\mathrm{TA}$ & $A$ & $A$ & $\mathrm{CA}$ & $A$ & $A$ & $A$ & $A$ & $A$ \\
\hline R. Perpustakaan & TA & TA & $\mathrm{TA}$ & TA & TA & TA & TA & $\mathrm{TA}$ & $\mathrm{CA}$ & TA & TA & TA & $\mathrm{CA}$ & TA & $\mathrm{CA}$ & $\mathrm{TA}$ \\
\hline R. Sosial & $A$ & $A$ & $A$ & $A$ & $A$ & $A$ & $A$ & $A$ & $A$ & $A$ & $\mathrm{CA}$ & $A$ & $A$ & $\mathrm{CA}$ & $A$ & $A$ \\
\hline R. Makan & $A$ & $A$ & $A$ & $A$ & $\mathrm{~A}$ & $\mathrm{~A}$ & $\mathrm{CA}$ & $\mathrm{A}$ & $A$ & $\mathrm{CA}$ & $\mathrm{A}$ & $\mathrm{A}$ & $\mathrm{A}$ & $A$ & $A$ & $A$ \\
\hline R. Cuci & TA & $\mathrm{CA}$ & $\mathrm{CA}$ & TA & TA & $\mathrm{A}$ & TA & $\mathrm{TA}$ & $\mathrm{CA}$ & TA & $\mathrm{CA}$ & TA & TA & $\mathrm{CA}$ & TA & TA \\
\hline R. Fisioterapi & $A$ & $A$ & $\mathrm{CA}$ & $A$ & $A$ & $\bar{A}$ & $A$ & $A$ & $A$ & $A$ & $A$ & $A$ & $A$ & $A$ & $A$ & $\bar{A}$ \\
\hline R. Asrama & $\mathrm{TA}$ & $A$ & $\mathrm{CA}$ & $\mathrm{CA}$ & TA & TA & $\mathrm{CA}$ & TA & $\mathrm{CA}$ & $\mathrm{CA}$ & $\mathrm{CA}$ & $\mathrm{CA}$ & $\mathrm{CA}$ & A & $\mathrm{CA}$ & $\mathrm{A}$ \\
\hline Toilet & $A$ & $A$ & $\mathrm{CA}$ & $A$ & $\mathrm{~A}$ & $\mathrm{CA}$ & $\mathrm{CA}$ & $A$ & $A$ & $\mathrm{CA}$ & $A$ & $A$ & $\mathrm{CA}$ & $\mathrm{A}$ & $\mathrm{CA}$ & $A$ \\
\hline
\end{tabular}

Keterangan:

$\mathrm{KR}=$ Kursi Roda, $\mathrm{K}=\mathrm{Kruk}$, DLL=Dan lain-lain, HP=Hasil Penelitian

$\mathrm{TA}=$ Tidak Aksesibel, $\mathrm{A}=$ Aksesibel, $\mathrm{CA}=$ Cukup Aksesibel 
LINTAS

RUANG | VOL. 1 | EDISI 1 | 2007

ISSN 1978-0702

ukuran dan bentuk, perabot dan penataannya, pencahayaan, dan penghawaan. Penghawaan dari ruang cuci membuat ruang sangat tidak aksesibel.

Aksesibilitas penyandang cacat tubuh di ruang fisioterapi sudah aksesibel jika dilihat dari ukuran dan bentuk, perabot dan penataannya, pencahayaan, dan penghawaan. Pengaruh perabot dan penataan dari ruang fisioterapi sangat signifikan terhadap aksesbilitas penyandang cacat tubuh.

Aksesibilitas penyandang cacat tubuh di ruang asrama sudah aksesibel jika dilihat penghawaan; cukup aksesibel dilihat dari ukuran dan bentuk serta pencahayaan; tidak aksesibel dilihat dari perabot dan penataannya.

Aksesibilitas penyandang cacat tubuh di ruang toilet sudah aksesibel jika dilihat dari ukuran dan bentuk, perabot dan penataannya, pencahayaan, dan penghawaan.

Berdasarkan analisis teori, pengaruh setting ruang terhadap aksesibilitas penyandang cacat tubuh terlihat pada jenis ruang yang ada di YAKKUM yaitu:

Aksesibilitas penyandang cacat tubuh di ruang resepsionis sudah aksesibel jika dilihat dari ukuran dan bentuk, perabot dan penataannya, pencahayaan, dan penghawaan.

Aksesibilitas penyandang cacat tubuh di ruang kantor sudah aksesibel jika dilihat dari ukuran dan bentuk, perabot dan penataannya, pencahayaan, dan penghawaan. Pencahayaan buatan di ruang kantor tidak aksesibel tetapi tidak berpengaruh pada aksesbilitas penyandang cacat tubuh karena aktivitas di ruang kantor tidak sampai malam.

Aksesibilitas penyandang cacat tubuh di ruang kelas sudah aksesibel jika dilihat dari ukuran dan bentuk, perabot dan penataannya, pencahayaan, dan penghawaan. Pencahayaan buatan di ruang

Tabel 3. Pengaruh Setting Ruang Terhadap Aksesibilitas Berdasarkan Analisis Teori

\begin{tabular}{|c|c|c|c|c|c|c|c|c|c|c|c|c|c|c|}
\hline \multirow[b]{2}{*}{ Jenis Ruang } & \multicolumn{4}{|c|}{$\begin{array}{c}\text { Ukuran \& } \\
\text { Bentuk }\end{array}$} & \multicolumn{3}{|c|}{$\begin{array}{l}\text { Perabot \& } \\
\text { Penataan }\end{array}$} & \multicolumn{4}{|c|}{ Pencahayaan } & \multicolumn{3}{|c|}{$\begin{array}{c}\text { Peng } \\
\text { hawaan }\end{array}$} \\
\hline & 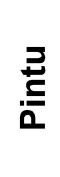 & 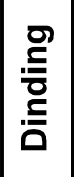 & 焉 & 모 & $\begin{array}{l}\text { 웅 } \\
\frac{0}{\pi} \\
\frac{\pi}{0} \\
0\end{array}$ & $\begin{array}{l}\frac{5}{\pi} \\
\stackrel{\pi}{\pi} \\
\stackrel{\pi}{\pi} \\
\mathbb{0} \\
0\end{array}$ & 呈 & $\begin{array}{l}\bar{E} \\
\frac{\bar{N}}{\alpha}\end{array}$ & 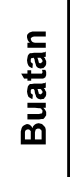 & $\frac{\frac{\pi}{\pi}}{\frac{x}{\pi}}$ & 呈 & $\frac{\vec{z}}{\vec{J}}$ & $\begin{array}{l}\overline{0} \\
\text { है } \\
\text { 음 }\end{array}$ & 鞊 \\
\hline R. Resepsionis & $\mathrm{A}$ & $\mathrm{CA}$ & $\mathrm{A}$ & $\mathbf{A}$ & $A$ & $A$ & A & $A$ & $\mathrm{~A}$ & - & $\mathbf{A}$ & $\mathrm{A}$ & - & A \\
\hline R. Kantor & $A$ & $\mathrm{CA}$ & $A$ & $A$ & $A$ & $A$ & A & $A$ & TA & $A$ & $\mathbf{A}$ & $A$ & $A$ & A \\
\hline R. Kelas & $\mathrm{CA}$ & $\mathrm{CA}$ & $\mathrm{A}$ & $\mathrm{A}$ & $\mathrm{A}$ & $\mathrm{A}$ & $A$ & $A$ & TA & $\mathrm{A}$ & A & $\mathrm{A}$ & $\mathrm{A}$ & A \\
\hline R. Perpustakaan & $\overline{C A}$ & TA & $\overline{T A}$ & TA & $\overline{T A}$ & $\overline{T A}$ & TA & $\mathrm{CA}$ & TA & $A$ & $\mathbf{C A}$ & $\mathrm{TA}$ & $A$ & CA \\
\hline R. Sosial & & $\bar{A}$ & $A$ & $A$ & $\mathrm{TA}$ & $A$ & CA & $A$ & $\mathrm{TA}$ & $A$ & $\mathbf{A}$ & $\mathrm{CA}$ & $A$ & A \\
\hline R. Makan & & $\mathrm{A}$ & $A$ & A & $\mathrm{TA}$ & $A$ & $\mathbf{C A}$ & $\mathrm{A}$ & $\mathrm{A}$ & $\mathrm{A}$ & $\mathbf{A}$ & $\mathrm{A}$ & - & $\mathbf{A}$ \\
\hline R. Cuci & - & $\mathrm{CA}$ & $A$ & A & $\mathrm{CA}$ & $A$ & A & $A$ & $A$ & $A$ & $\mathbf{A}$ & $A$ & $\mathrm{TA}$ & CA \\
\hline R. Fisioterapi & TA & $\mathrm{A}$ & $\mathrm{A}$ & $\mathbf{A}$ & $A$ & $\mathrm{~A}$ & $\mathbf{A}$ & $\mathrm{CA}$ & TA & $A$ & CA & $\mathrm{TA}$ & $A$ & CA \\
\hline R. Asrama & $A$ & $\mathrm{CA}$ & $A$ & $A$ & $\mathrm{TA}$ & $A$ & CA & $\mathrm{A}$ & $\mathrm{TA}$ & $\mathrm{TA}$ & TA & $\mathrm{CA}$ & & CA \\
\hline Toilet & TA & $C A$ & $A$ & CA & $A$ & $A$ & A & $A$ & $A$ & $A$ & A & $A$ & - & A \\
\hline
\end{tabular}

Keterangan:

HP=Hasil Penelitian, $T A=$ Tidak Aksesibel, $A=A$ ksesibel, $C A=C u k u p$ Aksesibel 
kantor tidak aksesibel tetapi tidak berpengaruh pada aksesbilitas penyandang cacat tubuh karena aktivitas di ruang kelas tidak sampai malam.

Aksesibilitas penyandang cacat tubuh di ruang perpustakaan tidak aksesibel jika dilihat dari ukuran dan bentuk, perabot dan penataannya; cukup aksesibel dilihat dari pencahayaan dan penghawaan. Pencahayaan buatan di ruang kantor tidak aksesibel tetapi tidak berpengaruh pada aksesibilitas penyandang cacat tubuh karena aktivitas di ruang kelas tidak sampai malam. Suhu di ruang perpustakaan menyebabkan penghawaan di ruang ini menjadi tidak aksesibel karena bukaan tertutupi oleh rakrak buku yang tinggi.

Aksesibilitas penyandang cacat tubuh di ruang sosial sudah aksesibel jika dilihat dari ukuran dan bentuk, pencahayaan, dan penghawaan; cukup aksesibel dilihat dari perabot dan penataannya. Perabot dari ruang sosial tidak aksesibel terhadap aksesbilitas penyandang cacat tubuh tetapi fungsi dari ruang sosial ini tidak hanya diperuntukkan untuk penyandang cacat saja tetapi untuk orang normal yang datang sebagai tamu ataupun keluarga. Pencahayaan buatan di ruang sosial tidak aksesibel, hal ini sedikit berpengaruh pada aksesbilitas penyandang cacat tubuh ketika menerima tamu di malam hari.

Aksesibilitas penyandang cacat tubuh di ruang makan sudah aksesibel jika dilihat dari ukuran dan bentuk, pencahayaan, dan penghawaan; cukup aksesibel dilihat dari perabot dan penataannya. Perabot di ruang makan tidak aksesibel bagi semua penyandang cacat tubuh yaitu bangku dan rak televisi.

Aksesibilitas penyandang cacat tubuh di ruang cuci aksesibel jika dilihat dari ukuran dan bentuk, perabot dan penataannya, pencahayaan; cukup aksesibel dilihat dari penghawaan. Walau suhu di ruang cuci sudah sesuai standar tetapi penempatan tombol kipas angin yang sulit dijangkau oleh pemakai kursi roda serta tingginya bukaan (ventilasi) membuat penghawaan dari ruang cuci sangat tidak aksesibel.

Aksesibilitas penyandang cacat tubuh di ruang fisioterapi sudah aksesibel jika dilihat dari ukuran dan bentuk, perabot dan penataannya; cukup aksesibel dilihat dari pencahayaan dan penghawaan. Pintu, pencahayaan buatan dan suhu membuat ruang fisioterapi tidak aksesibel.

Aksesibilitas penyandang cacat tubuh di ruang asrama sudah aksesibel jika dilihat ukuran dan bentuk; cukup aksesibel dilihat dari perabot dan penataannya serta penghawaan; tidak aksesibel dilihat dari pencahayaan. Ketidak aksesibelan dipengaruhi perabot yang tidak ergonomik bagi penyandang cacat tubuh, pencahayaan buatan yang tidak mencukupi untuk aktivitas malam hari dan perletakan saklar lampu yang terlalu tinggi.

Aksesibilitas penyandang cacat tubuh di ruang toilet sudah aksesibel jika dilihat dari perabot dan penataannya, pencahayaan, dan penghawaan; cukup aksesibel dilihat dari ukuran dan bentuk. Walau ukuran pintu sudah sesuai standar tetapi pintu sulit dibuka/tutup karena handel terlalu tinggi, pintu tidak memiliki handgrap dan plat tendang.

Berdasarkan analisis SPSS dan analisis teori didapat pengaruh setting ruang dari masing-masing ruang terhadap aksesbilitas (Lihat Tabel 4) adalah sebagai berikut:

Aksesibilitas penyandang cacat tubuh di ruang resepsionis sudah aksesibel yang dipengaruhi oleh jenis perabot dan penataannya, pencahayaan dan penghawaan. Ukuran dan bentuk ruang resepsionis yang terbuka tidak membuat ruang ini aksesibel hal ini terlihat dari perilaku pemakai kursi roda melakukan penyesuaian terhadap ruang yang ada (adjusment) dalam bersirkulasi dengan tidak berputar di dalam ruang namun mundur dulu, baru berbelok keluar ruang resepsionis.

Aksesibilitas penyandang cacat tubuh di ruang kantor sudah aksesibel yang dipengaruhi oleh pencahayaan dan penghawaan. Ukuran dan bentuk serta perabot dan penataan di ruang kantor sudah sesuai standar sehingga penyandang cacat merasa cukup aksesibel.

Aksesibilitas penyandang cacat tubuh di ruang kelas sudah aksesibel yang dipengaruhi oleh pencahayaan dan penghawaan. Berdasarkan teori, ukuran dan bentuk serta perabot dan penataanya sudah aksesibel tetapi penilaian responden berbeda 
RUSTS

dimana ukuran dan bentuk dari ruang kelas cukup aksesibel dan perabot dan penataan aksebilitas suatu ruang. Ruang perpustakaan memiliki ukuran yang sempit karena awalnya ruang ini berfungsi sebagai ruang kelas. Selain itu banyaknya perabot berupa rak-rak membuat bentuk ruang terkesan terkotakkotak. Dari segi perilaku penyandang cacat terhadap kekurangan aksesibilitas pada ukuran dan bentuk ruang serta kekurangan elemen pendukung pada pintu dengan melakukan penyesuaian (adjusment).

Perabot yang ergonomis sesuai tubuh penyandang cacat tubuh dan penataan perabot yang menyediakan area sirkulasi bagi semua penyandang cacat tubuh memberi pengaruh pada aksesibilitas di ruang fisioterapi, resepsionis, dan toilet. Perabot di ruang perpustakaan tidak aksesibel bagi penyandang cacat tubuh dan area sirkulasi pada penataan perabot menciptakan area sirkulasi yang tidak sesuai dengan ruang gerak penyandang cacat tubuh terutama pemakai kursi roda. Dari segi perilaku, penyandang cacat melakukan penyesuaian (adjusment) terhadap kekurangan aksesibilitas pada ukuran dan bentuk perabot serta penataannya.

Pencahayaan alami di ruang resepsionis, kelas, toilet, makan, sosial, kantor memiliki pengaruh terhadap aksesibilitas penyandang cacat tubuh dilihat dari segi fungsi. Ketinggian perletakan saklar yang dapat dicapai oleh semua penyandang cacat juga mempengaruhi aksebilitas dilihat dari segi teknis. Dari segi perilaku, penyandang cacat melakukan penyesuaian (adjusment) terhadap ukuran ketinggian saklar yang tidak aksesibel.

Suhu di ruang kelas, resepsionis, sosial, makan, kantor, toilet memiliki pengaruh terhadap aksesibilitas penyandang cacat tubuh dilihat dari segi fungsi. Ketinggian perletakan saklar kipas angin yang dapat dicapai oleh semua penyandang cacat juga mempengaruhi aksebilitas dilihat dari segi teknis. Dari segi perilaku, penyandang cacat melakukan penyesuaian (adjusment) terhadap ukuran ketinggian saklar yang tidak aksesibel.

Pengaruh setting ruang terhadap aksesibilitas para penyandang cacat tubuh terlihat pada jenis ruang yang ada di YAKKUM yaitu: aksesibilitas penyandang cacat tubuh di ruang resepsionis sudah aksesibel yang 
Tabel 4. Pengaruh Setting Ruang Terhadap Aksesibilitas

\begin{tabular}{|c|c|c|c|c|c|c|c|c|}
\hline \multirow[b]{2}{*}{ Jenis Ruang } & \multicolumn{4}{|c|}{ Analisis SPSS } & \multicolumn{4}{|c|}{ Analisis Teori } \\
\hline & 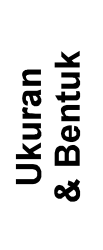 & 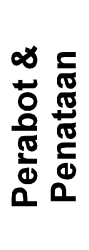 & 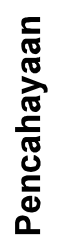 & 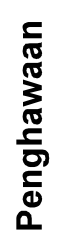 & 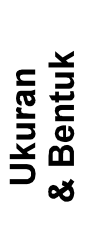 & 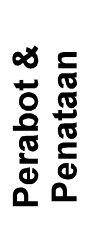 & 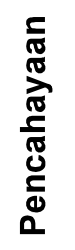 & 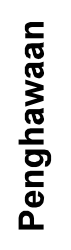 \\
\hline R. Resepsionis & $\mathrm{TA}$ & $\mathrm{A}$ & $\mathrm{A}$ & $\mathrm{A}$ & $A$ & $\mathrm{~A}$ & $A$ & $A$ \\
\hline R. Kantor & $\mathrm{CA}$ & $\mathrm{CA}$ & $A$ & $A$ & $A$ & $\bar{A}$ & $A$ & $A$ \\
\hline R. Kelas & $\mathrm{CA}$ & TA & $A$ & $A$ & $A$ & $\mathrm{~A}$ & $A$ & $A$ \\
\hline R. Perpustakaan & TA & TA & $\mathrm{TA}$ & TA & $\mathrm{TA}$ & $\mathrm{TA}$ & $\mathrm{CA}$ & $\mathrm{CA}$ \\
\hline R. Sosial & $A$ & $A$ & $\mathrm{~A}$ & $A$ & $A$ & $\mathrm{CA}$ & $A$ & $A$ \\
\hline R. Makan & $A$ & $A$ & $A$ & $A$ & $A$ & $\mathrm{CA}$ & $A$ & $A$ \\
\hline R. Cuci & $\overline{T A}$ & TA & $\overline{T A}$ & TA & $\bar{A}$ & $A$ & $A$ & $\mathrm{CA}$ \\
\hline R. Fisioterapi & $A$ & $A$ & $A$ & $A$ & $A$ & $\mathrm{~A}$ & $\mathrm{CA}$ & $\mathrm{CA}$ \\
\hline R. Asrama & $\mathrm{CA}$ & TA & $\mathrm{CA}$ & $\mathrm{A}$ & $\mathrm{A}$ & $\mathrm{CA}$ & TA & $\mathrm{CA}$ \\
\hline Toilet & $A$ & $\bar{A}$ & $A$ & $\mathrm{~A}$ & $\mathrm{CA}$ & $A$ & $A$ & $A$ \\
\hline
\end{tabular}

Keterangan:

$\mathrm{TA}=$ Tidak Aksesibel, $\mathrm{A}=\mathrm{Aksesibel}, \mathrm{CA}=$ Cukup Aksesibel

dipengaruhi jenis perabot dan penataannya, pencahayaan dan penghawaan. Ukuran dan aksesibel. Ukuran pintu ruang tidak terlalu berpengaruh pada aksesibilitas, tetapi handel, handgrap dan plat tendang sangat berpengaruh pada aksesibilitas suatu ruang. Dari segi perilaku, penyandang cacat melakukan penyesuaian (adjusment) terhadap kekuranganaksesibelan pada ukuran dan bentuk ruang serta kekurangan elemen pendukung pada pintu.

Perabot yang ergonomis sesuai dengan antropometri tubuh penyandang cacat dan penataan perabot yang menyediakan area sirkulasi bagi semua penyandang cacat tubuh memberi pengaruh pada aksesibilitas di setting ruang. Dari segi perilaku, penyandang cacat melakukan penyesuaian (adjusment) terhadap kekurangaksesibelan pada ukuran dan bentuk perabot serta penataannya.

Pencahayaan alami memiliki pengaruh terhadap aksesibilitas dilihat dari segi fungsi. Ketinggian perletakan saklar mempengaruhi aksebilitas dilihat dari segi teknis. Dari segi perilaku, penyandang cacat 
melakukan penyesuaian (adjusment) terhadap kekurangaksesibelan pada ukuran ketinggian saklar.

\section{DAFTAR PUSTAKA}

Darmasetiawan, Christian \& Puspakesuma, Lestari. 1999. Tehnik Pencahayaan dan Tata Letak Lampu. Jakarta: Gramedia Widiasarana Indonesia.

DeChiara, J, Panero, J \& Zelnik, M. 2001. Time Saver Standards for Interior Design and Space Planning. New York: McGraw-Hill Book Company.

Departemen Pekerjaan Umum. 1998. Keputusan Menteri Pekerjaan Umum RI No. 468/KPPS/1998. 1998 : Persyaratan Teknis Aksesibilitas Pada Bangunan Umum dan Lingkungan. Jakarta.

Haryadi, B. Setiawan, 1995. Arsitektur Lingkungan dan Perilaku. Proyek Pengembangan Pusat Studi Lingkungan. Direktorat Jendral Pendidikan Tinggi Departemen Pendidikan Dan kebudayaan, Republik Indonesia.

Holmes, James-Siedle. 1998. Barrier-Free Design, A Manual for Building Designer and Managers. Oxford:Architectural Press.

Reinhold, Kohler. 1959. Lighting in Architecture. New York: Reinhold Publising. Co.

Neufert, Ernst. 1989. Data Arsitek. Jakarta: Penerbit Erlangga.

Sastrowinoto, Suyatno.1985. Meningkatakan Produktivitas dengan Ergonomi. Jakarta: PT. Pustaka Binaman Pressindo.

Sorenson, Robert James. 1979. Design for Accessibility. New York: McGraw-Hill Book Company.

Suma'mur, P.K. 1989. Ergonomi untuk Produltivitas Kerja. Jakarta: CV.Haji Masagung.

Weismann, G.,1981, Modelling Environmental Behaviour Systems. Journal of ManEnvironment Relations.

Wignjosoebroto, Sritomo. 1995. Ergonomi: Studi Gerakdan Waktu.Jakarta: Guna Widya. 
M. SHOLAHUDDIN

Setting Ruang dan Pengaruhnya Terhadap Aksesibilitas Para Penyandang Cacat Tubuh di Pusat Rehabilitasi YAKKUM Yogyakarta | hal $31-41$ 